\title{
Successful Preoperative Treatment by Plasmapheresis of Hyperthyroidism with Hydatidiform Mole
}

\section{Molar Gebelik Sonucu Gelişen Hipertiroidizm Olgusunda Plazmaferez Tedavisi}

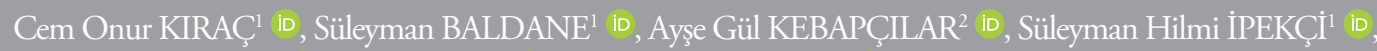

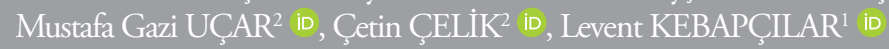

${ }^{1}$ Department of Internal Medicine, Division of Endocrinology, Selcuk University School of Medicine, Konya, Turkey

${ }^{2}$ Department of Obstetrics and Gynaecology, Selcuk University School of Medicine, Konya, Turkey

\section{ABSTRACT}

We recently encountered the case of an 18-year-old female complaining of abdominal pain, fatigue, nausea, vomiting, tremor of the hands, and vaginal bleeding. Her blood test revealed highly elevated human chorionic gonadotropin (hCG) levels, suppressed thyroid-stimulating hormone (TSH) levels, and increased free thyroid hormone levels. Molar pregnancy and hyperthyroidism were suspected based on highly elevated hCG levels and suppressed TSH levels with the co-existence of ultrasonographic findings of the uterus and thyroid Doppler images. Her symptoms and thyroid hormone levels responded well to plasmapheresis. Subsequently, the patient underwent dilatation and curettage for hydatidiform mole. Histopathology of the products verified the diagnosis of complete hydatidiform mole with no invasion. The patient is currently stable, and her hCG and thyroid hormone levels are within normal reference ranges.

Keywords: Hydatidiform mole, hCG, hyperthyroidism, plasmapheresis

\section{öz}

18 yaşında kadın hasta karın ağrısı, yorgunluk, bulantı, kusma, ellerde titreme ve vajinal kanama şikayeti ile başvurdu. Laboratuvar tetkiklerinde artmış human chorionic gonadotropin (hCG), baskılanmış tiroid stimulan hormon (TSH) ve artmış serbest tiroid hormon düzeyleri görüldü. Laboratuar tetkikleri ile birlikte tiroid doppler ve uterus ultrasonografi incelemesi sonucunda molar gebelik sonucu gelişen hipertiroidizm tanısı düşünüldü. Plazmaferez tedavisi ile hastanın semptomların da düzelme ve serbest tiroid hormonlarında normal düzeye gerileme sağlandı. Plazmaferez tedavisi sonrası hastaya dilatasyon ve küretaj tedavisi uygulandı. Histopatolojik incelemede non-invaziv mol hidatiform tanısı doğrulandı.

Anahtar Kelimeler: Mol hidatiform, hCG, hipertiroidizm, plazmaferez

\section{Introduction}

Hydatidiform mole (HM) is the most frequently encountered form of gestational trophoblastic disease and fetal developmental defect, where abnormal trophoblast cells develop inside the uterus following conception (1). The incidence rate ranges from 1 in 500 to 1 in 1500 pregnancies in western developed countries (1). The high hCG levels induced by HM may also induce hyperthyroidism caused by accelerated synthesis of thyroid hormones; typically, patients present with vaginal bleeding (2). The objective of this report is to present a case in which plasmapheresis was administered to control thyroid hormones in hyperthyroidism with a hydatidiform mole.

\section{Case Report}

An 18-year-old woman presented to the gynecology and obstetrics service with abdominal pain, nausea, vomiting, and vaginal bleeding for 2 days. Her last normal menstrual period was a month prior and she had an unremarkable medical history. She was married with no children and reported no tobacco use. Physical examination revealed that she was tachycardic (110 bpm), dehydrated, experienced tremor of the hands, and had a normal blood pressure of 112/66 mmHg. Cardiac assessment yielded normal values of echocardiographic measurements, except for sinus tachycardia yielded on

Cite this article as: Kıraç CO, Baldane S, Kebapçılar AG, İpekçi SH, Uçar MG, Çelik Ç, et al. Successful Preoperative Treatment by Plasmapheresis of Hyperthyroidism with Hydatidiform Mole. Bezmialem Science 2018; 6(4): 320-2. 
electrocardiography. The uterus size was consistent with that associated with a 16-week gestation. Ultrasound revealed that the uterine cavity was significantly extended and filled with an echogenic soft-tissue mass that had small cystic components, most compatible with complete molar pregnancy.

Her hCG levels were over 250,000 $\mathrm{mIU} / \mathrm{mL}$, thyroid-stimulating hormone (TSH) level was $0.013 \mu \mathrm{IU} / \mathrm{L}(0.27-4.2$ $\mu \mathrm{IU} / \mathrm{L}$ ), free thyroxine (fT4) was $3.4 \mathrm{ng} / \mathrm{dL}(0.93-1.7 \mathrm{ng} / \mathrm{dL}$ ), and free triiodothyronine (fT3) was $8.1 \mathrm{ng} / \mathrm{dL}(2.0-4.4 \mathrm{ng} /$ $\mathrm{dL})$. Other blood tests, such as hemogram, leukocytes, and renal and liver function tests, were normal. The patient was transferred to an endocrinology department for diagnosis and treatment of hyperthyroidism before uterine curettage with general balanced anesthesia.

We detected hypervascularization of the thyroid gland on Doppler ultrasound examination. Based on power Doppler sonographic findings and thyroid hormone levels, she was diagnosed with hyperthyroidism. She received methimazole at a dose of $40 \mathrm{mg}$ daily and was initiated with $\beta$-receptor antagonist therapy and dexamethasone treatment. To rapidly displace the thyroid hormones from the body for better hormonal control, plasmapheresis was administered to the patient prior to surgery. One session of plasmapheresis was administered to the patient on the first day, which lasted for approximately $3 \mathrm{~h}$. No complications developed during or after the procedures. During plasmapheresis, $3,000 \mathrm{~mL}$ of plasma was collected from the patient, and the same volume of fresh frozen plasma was given to the patient. At the time of surgery, on the second day after admission, her serum fT4 and $\mathrm{ft} 3$ levels were $2.3 \mathrm{ng} / \mathrm{dL}$ and $5.1 \mathrm{ng} / \mathrm{dL}$, respectively.

Subsequently, the patient underwent dilatation and curettage for evacuation of the mole. There were no complications during surgery or postoperatively. At 36-48 hours postoperatively, her hCG levels decreased to $77.724 \mathrm{mIU} / \mathrm{mL}$. Histopathology of the products verified the diagnosis of complete hydatidiform mole with no invasion. The patient is currently stable, and her hCG and thyroid hormone levels are within normal reference ranges. Written informed consent was obtained from the patient.

\section{Discussion}

HM with hyperthyroidism is a rare clinical condition, but thyroid hyperstimulation by highly elevated hCG may have triggered the cardiopulmonary system (3). Most people with HM do not have hyperthyroidism; however, women with HM have an increased risk of developing hyperthyroidism (2). In a retrospective study, biochemical hyperthyroidism was $7 \%$ and clinical hyperthyroidism was only $2 \%$ in 196 female patients with HM (4). HM occasionally co-exists with markedly elevated hCG levels, as can be observed in our patient, who had an hCG level of approximately half a million $\mathrm{mIU} / \mathrm{mL}$ (5). Markedly elevated glycoprotein hormone, hCG, is the primary diagnostic indicator of HM (5). The similarity between
hCG and TSH can induce cross-reactivity in their receptors. This similarity between hCG and TSH molecules can cause hyperthyroidism (6). Glinoer reported that for every 10,000 $\mathrm{mU} / \mathrm{mL}$ upregulation in serum hCG, $\mathrm{fT} 4$ increases by 0.1 $\mathrm{ng} / \mathrm{dL}$ and TSH reduces by $0.1 \mathrm{mIU} / \mathrm{mL}$ (7). When gestational trophoblastic disease causes a significant upregulation in hCG levels, it may produce hyperthyroidism that requires urgent treatment. Elective surgery and treatment should be postponed until the patient becomes euthyroid. In instances of emergency surgery, such as in the present case, it may not be possible to wait 1 week for the thyroid hormone levels to stabilize. As expected, hyperthyroidism resolves with curettage for evacuation of the mole and normalization of hCG levels (2). However, lack of preoperative control of the thyrotoxic state considerably increases the risk of thyroid storm. The thyroid storm associated with surgery can manifest intraoperatively but is more likely to occur 6-18 hours postoperatively (8). Untreated hyperthyroid crisis (thyroid storm) is typically fatal. The mortality rate of the thyroid storm is currently approaching 30\% despite early recognition and adequate treatment (8).

While HM can be eradicated by simple curettage, untreated molar pregnancies the incidence of acute respiratory complications increased to $27 \%$ (9). In the literature survey, we found that unaddressed hyperthyroidism with HM can induce acute respiratory insufficiency, a known complication of molar pregnancies occurring in $8-11 \%$ of cases and up to as many as $50 \%(10)$. Untreated HM with hyperthyroidism is typically fatal $(10,11)$. Because the subsequent prolongation of thyroid function impairment could induce respiratory insufficiency and in molar pregnancy with hyperthyroidism, patients have encountered acute cardiopulmonary distress following suction evacuation under general anesthesia and massive trophoblastic embolism, death may occur $(10,11)$.

Antithyroid medications are frequently used to treat hyperthyroidism (12). However, antithyroid drugs cannot achieve complete control of thyroid hormone levels rapidly and typically require at least 3 weeks to reduce thyroid hormone levels (12). To avoid the risk of thyroid storm and respiratory insufficiency because of both of these diseases, plasmapheresis was selected before surgery.

\section{Conclusion}

In the literature survey, four case reports (13-15) showed that plasmapheresis was used to treat hyperthyroidism with hydatidiform mole. We suggest that plasmapheresis management be considered a suitable choice when life-threatening hyperthyroidism is encountered in women with HM.

Informed Consent: Written informed consent was obtained from the patient who participated in this study.

Peer-review: Externally peer-reviewed. 
Author Contributions: Concept - C.O.K., S.B.; Design - C.O.K., S.B.; Supervision - S.B., L.K., Ç.Ç.; Resources - S.H.I., A.K.; Materials - A.K., M.U.; Data Collection and/or Processing - C.O.K., M.U.; Analysis and/or Interpretation - S.H.İ., L.K., Ç.Ç.; Literature Search - A.K., M.U.; Writing Manuscript - C.O.K., S.B.; Critical Review - S.H.İ., L.K., Ç.Ç.

Conflict of Interest: The authors have no conflicts of interest to declare.

Financial Disclosure: The authors declared that this study has received no financial support.

Hasta Onamı: Yazılı hasta onamı bu çalışmaya katılan hastadan alınmıştır.

Hakem Değerlendirmesi: Dış bağımsız.

Yazar Katkıları: Fikir - C.O.K., S.B.; Tasarım - C.O.K., S.B.; Denetleme - S.B., L.K., Ç.Ç.; Kaynaklar - S.H.İ., A.K.; Veri Toplanması ve/veya İşlemesi - C.O.K., M.U.; Analiz ve/veya Yorum - S.H.İ., L.K., Ç.Ç.; Literatür Taraması - A.K., M.U.; Yazıyı Yazan - C.O.K., S.B.; Eleştirel İnceleme - S.H.İ., L.K., Ç.Ç.

Çıkar Çatışması: Yazarlar çıkar çatışması bildirmemişlerdir.

Finansal Destek: Yazarlar bu çalışma için finansal destek almadıklarını beyan etmişlerdir.

\section{References}

1. Seckl MJ, Sebire NJ, Berkowitz RS. Gestational trophoblastic disease. Lancet 2010; 376: 717-29. [CrossRef]

2. Drury MI, Sugrue DD, Drury RM. A review of thyroid disease in pregnancy. Clin Exp Obstet Gynecol 1984; 11: 79-89.

3. Kohorn EI. Clinical management and the neoplastic sequelae of trophoblastic embolization associated with hydatidiform mole. Obstet Gynecol Surv 1987; 42: 484-8. [CrossRef]
4. Garner E, Goldstein DP, Feltmate CM, Berkowitz RS. Gestational trophoblastic disease. Clin Obstet Gynecol 2007; 50: 112-22. [CrossRef]

5. Menczer J, Modan M, Serr DM. Prospective follow-up of patients with hydatidiform mole. Obstet Gynecol 1980; 55: 3469. [CrossRef]

6. Yoshimura M, Hershman JM. Thyrotropic action of human chorionic gonadotropin. Thyroid 1995; 5: 425-34. [CrossRef]

7. Glinoer D. The regulation of thyroid function in pregnancy: pathways of endocrine adaptation from physiology to pathology. Endocr Rev 1997; 18: 404-33. [CrossRef]

8. Tietgens ST, Leinung MC. Thyroid storm. Med Clin North Am 1995; 79: 169-84. [CrossRef]

9. Twiggs LB, Morrow CP, Schlaerth JB. Acute pulmonary complications of molar pregnancy. Am J Obstet Gynecol 1979; 135: 189-94. [CrossRef]

10. Bhatia S, Naithani U, Chhetty YK, Prasad N, Jagtap SR, Agrawal I. Acute pulmonary edema after evacuation of molar pregnancy. Anaesthesia Pain and Intensive Care 2011; 15: 1147.

11. Celeski D, Micho J, Walters L. Anesthetic implications of a partial molar pregnancy and associated complications. AANA J 2001; 69: 49-53.

12. Franklyn JA. The management of hyperthyroidism. N Engl J Med 1994; 330: 1731-8. [CrossRef]

13. Erbil Y, Tihan D, Azezli A, Salmaslioğlu A, Ozlük Y, Büyükören A, et al. Severe hyperthyroidism requiring therapeutic plasmapheresis in a patient with hydatidiform mole. Gynecol Endocrinol 2006; 22: 402-4 [CrossRef]

14. Azezli A, Bayraktaroglu T, Topuz S, Kalayoglu-Besisik S. Hyperthyroidism in molar pregnancy: rapid preoperative preparation by plasmapheresis and complete improvement after evacuation. Transfus Apher Sci 2007; 36: 87-9. [CrossRef]

15. Adali E, Yildizhan R, Kolusari A, Kurdoglu M, Turan N. The use of plasmapheresis for rapid hormonal control in severe hyperthyroidism caused by a partial molar pregnancy. Arch Gynecol Obstet 2009; 279: 569-71. [CrossRef] 